\title{
Effect of different level of concentrate supplementation on the periparturient growth performance of Ganjam goat in extensive system
}

\author{
Subhasish Sahu ${ }^{1}$, Laxman Kumar Babu², Dilip Kumar Karna², Kumaresh Behera², Sudesh Kanungo ${ }^{2}$, Sandeep Kaswan $^{1}$, \\ Probhakar Biswas ${ }^{1}$, Jitendra Kumar Patra ${ }^{1}$ \\ 1. Indian Veterinary Research Institute, Izatnagar - 243122, Dist. Bareilly (UP) India; 2. College of Veterinary Science \\ and Animal Husbandry, Orissa University of Agriculture and Technology, Bhubaneswar, Orissa, India \\ Corresponding author: Subhasish Sahu, email: subhasishsahu72@gmail.com \\ Received: 07-11-2012, Accepted: 22-11-2012, Published online: 26-04-2013
}

How to cite this article: Sahu S, Babu LK, Karna DK, Behera K, Kanungo S, Kaswan S, Biswas P, Patra JK (2013) Effect of different level of concentrate supplementation on the periparturient growth performance of Ganjam goat in extensive system, Vet World 6(7): 428-432, doi: 10.5455/vetworld.2013.428-432

\begin{abstract}
Aim: The present study was carried out to evaluate the impact of concentrate supplementation to the pregnant Ganjam goats on their growth performance in periparturient period.

Materials and Methods: A total of 45 pregnant Ganjam does of similar body weight, age and parity were divided into three treatment groups with 15 does in each. $\mathrm{T}_{1}$ : normal browsing at range system, $\mathrm{T}_{2}$ : normal browsing with concentrate supplementation@200g/day, $\mathrm{T}_{3}$ : normal browsing with concentrate supplementation@300g/day for 60 days before expected date of kidding. Observations regarding various growth performances were made following standard procedures.

Results: Average daily concentrate feed intake for $\mathrm{T}_{2}$ was $160 \mathrm{~g}$ and $225 \mathrm{~g}$ for $\mathrm{T}_{3}$. For the does in $\mathrm{T}_{1}$, the body weights ranged from $34.59 \pm 0.75 \mathrm{~kg}$ (at the beginning) to $38.29 \pm 0.75 \mathrm{~kg}$ (after 60 days of supplementation) while for those in $\mathrm{T}_{2}$ it increased from $33.91 \pm 0.70 \mathrm{~kg}$ to $38.71 \pm 0.64 \mathrm{~kg}$ and for $\mathrm{T}_{3}$ it ranged from $34.05 \pm 0.64$ to $39.55 \pm 0.62 \mathrm{~kg}$. The cumulative live weight gain during the period 0-60 days varied significantly among the different treatments with the lowest value in $\mathrm{T}_{1}(3.71 \pm 0.27 \mathrm{~kg})$ to highest value in $\mathrm{T}_{3}(5.49 \pm 0.22 \mathrm{~kg}$ ) although the initial body weights were same. The cumulative body weight gain during 0 90 days postpartum was significantly higher in $\mathrm{T}_{1}(3.13 \pm 0.46 \mathrm{~kg})$ compared to $\mathrm{T}_{3}(2.10 \pm 0.19 \mathrm{~kg})$. Significant difference in average daily gain during prepartum period was found in all groups as $61.78 \pm 4.47,79.89 \pm 2.20,91.56 \pm 3.71$ for $\mathrm{T}_{1}, \mathrm{~T}_{2}$, and $\mathrm{T}_{3}$ respectively. The average daily gain of the does during post partum period was $23.33 \mathrm{~g}\left(\mathrm{~T}_{3}\right), 24.30 \mathrm{~g}\left(\mathrm{~T}_{2}\right)$ and $34.81 \mathrm{~g}\left(\mathrm{~T}_{1}\right)$ per doe indicating a statistically significant difference among the treatments.
\end{abstract}

Conclusion: It is concluded that on supplementation of concentrate between 160 to $225 \mathrm{~g}$ improved both prepartum and postpartum body condition of Ganjam goats.

Key words: body weight, concentrate, Ganjam goat, pregnant

\section{I ntroduction}

In India goats are called as "poor man's cow". The goats distributed throughout the country are divided into five major zones viz. Temperate Himalayan Region, Dry North Western Region, Central Region, Southern Region and Eastern Region. Ganjam goat is widely distributed in the whole of Ganjam district along with parts of Gajapati. This breed has been a major source of livelihood of Golla tribe since generations and therefore also known as 'Golla goats'. These goats are reared under extensive system of management without any supplementary feed. Nearby range and forest land mostly serve as the feed source for these goats. Concentrate supplementation to goat at various stages enhance their performances [1-3]. Particularly, in mid pregnancy, the nutrient requirements of foetus are still low, but placenta must grow at this time and if growth of placental tissue is restricted by low plane of nutrition, it will be unable to adequately

This article is an open access article licensed under the terms of the Creative Commons Attribution License (http://creativecommons. org/licenses/by/2.0) which permits unrestricted use, distribution and reproduction in any medium, provided the work is properly cited. nourish the foetus in final stage of pregnancy and consequently birth weight will be compromised [4,5]. Rapid rate of foetal growth during the final 6-8 weeks of pregnancy imposes a metabolic challenge to the doe which is met by the mobilisation of maternal body tissue [6] and this may result in weight loss of doe if the dietary supply of nutrients is inadequate [5-9]. An unscientific approach to animal feeding during pregnancy may lead to reproductive wastage resulting from either abortion or neonatal death due to low birth weight resulting from malnutrition of pregnant does [10-12]. Supplemental feeding might be a possible way to overcome the above situation.

Pre-partum feeding is aimed at higher birth weights, lower kid mortality and higher growth rate of the kids. Maintenance of good health of does ensures good supply of nutrients to the kids both during pregnancy and preweaning period. Some encouraging results have been obtained by many workers by prepartum supplementation [13-15].

Considering the above facts in mind the present study was undertaken to study the effect of balanced concentrate supplement to the pregnant Ganjam does in late gestation on their body weight gain. 


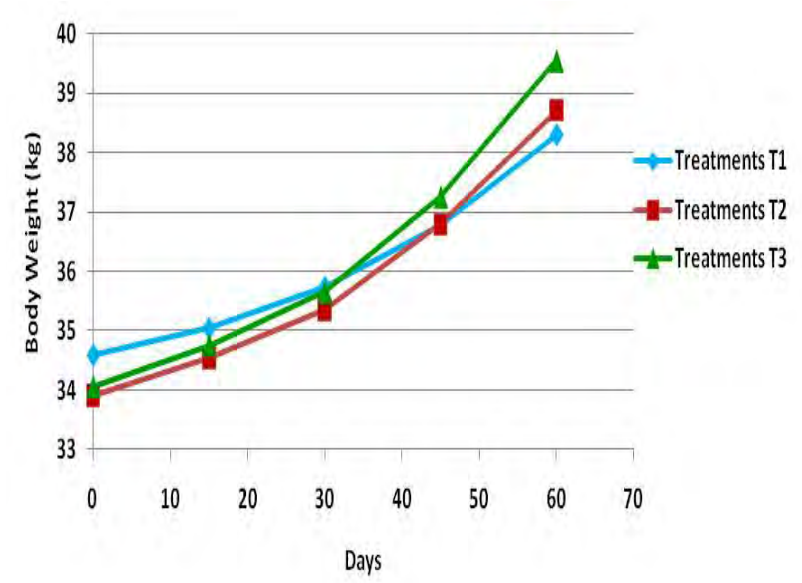

Figure-1. Pre-partum body weight $(\mathrm{kg})$ of does at 15 days interval.

\section{Materials and Methods}

Study area: The study was carried out in Podapadar village of Chhatrapur block in Ganjam district of Orissa where AICRP on Goat Improvement (Ganjam Field Unit) is operating. The study area is situated 145 $\mathrm{km}$ away from the College of Veterinary Science and Animal Husbandry, Bhubaneswar. These areas are dominated by 'Golla' people, who rear Ganjam goats traditionally in large number in range system. The animals selected were from the flocks of registered goat farmers of the project.

Ethical approval: The experiment followed the guidelines of Institutional Animal Ethics Committee.

Animals: For this study, Ganjam goats (does) of similar body weight, age and parity ( $3^{\text {rd }}$ to $5^{\text {th }}$ parity) were selected. The expected dates of kidding were estimated as per the breeding history of goat given by the flock man. Total 45 healthy pregnant does were taken for this study. The selected does were randomly allotted to three treatment groups based on complete randomized design, each compromising 15 pregnant does. The pregnant goats were divided into three groups of 15 does each and kept in different feeding regimens as follows

Treatment -1 $\left(\mathrm{T}_{1}\right)$ : Control; normal browsing at range system

Treatment - $2\left(\mathrm{~T}_{2}\right)$ : Control plus daily supplementation @ $200 \mathrm{~g}$ concentrate

Treatment - $3\left(\mathrm{~T}_{3}\right)$ : Control plus daily supplementation @ $300 \mathrm{~g}$ concentrate

The concentrate mixture was fed to the does 60 days before the expected date of kidding. The ingredient composition of the concentrate mixture contained Maize, Groundnut oil cake, Rice polish, Wheat bran, Mineral mixture and Common salt in 40, $26,10,22,1.5$ and 0.5 respectively. This concentration mixture contained $22 \%$ crude protein (estimated) with $72 \%$ Total Digestible Nutrients (calculated). Five days adaptation period for concentrate feeding was provided to the treatment groups. At the time of concentrate feeding in very early morning, the goats were separated

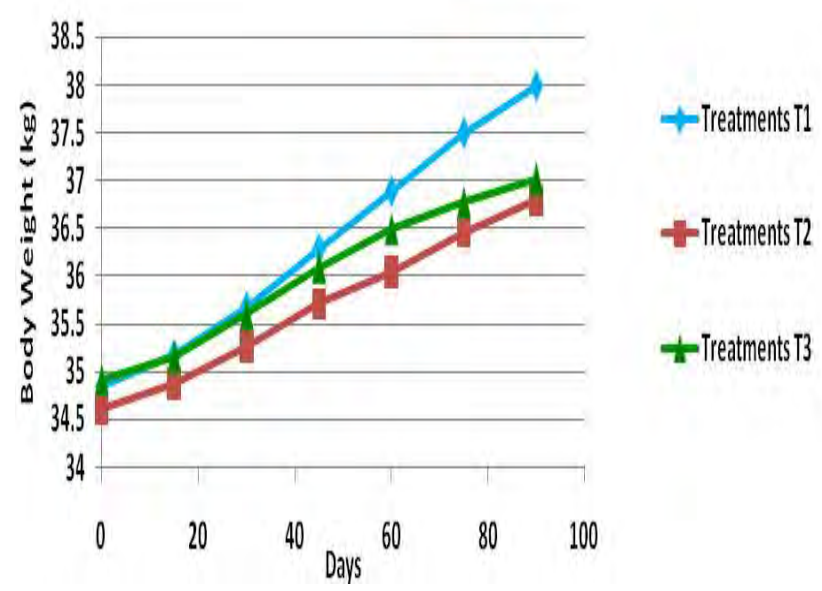

Figure-2. Post-partum body weight $(\mathrm{kg})$ of does at 15 days interval.

as per their treatment group by confining them in partition wall made up of bamboo. Left over residues of the previous day fed concentrate were weighed first before offering the known quantity of concentrate feed to the respective treatment groups for the same day.

The individual body weight of the does was recorded at the beginning of the experiment and subsequently at 15 days intervals in the morning hours before feeding and watering consecutively for 2 days and average weight was taken on $0,15,30,45$ and 60 days of experimental feeding (prepartum) and 0,15 , $30,45,60,75$ and $90^{\text {th }}$ day of postpartum.

The study was conducted for a period of five months (60 days pre partum and 90 days post partum) from mid November' 2010 to mid April' 2011 for a duration of 150 days during early winter to early summer season.

Statistical analysis: The statistical analysis of data was done by adopting standard procedures as described by earlier scientist [16].

\section{Results and Discussion}

The average daily concentrate feed intake per does in treatment group 2 was found to be $160 \mathrm{~g}$ out of $200 \mathrm{~g}$ daily supplementation while for treatment 3 it was $225 \mathrm{~g} /$ doe/day out of $300 \mathrm{~g}$ concentrate supplementation.

The mean prepartum body weights for the does in three different groups measured at 15 days interval are presented in Figure-1. The initial body weights of the pregnant does were non-significantly different (ranging from $33.91 \pm 0.70$ to $34.59 \pm 0.75 \mathrm{~kg}$ ) as the does were selected according to their body weight, age and parity. The body weights of the does in the three treatment groups increased with the advancement in pregnancy till parturition reaching the final body weight ranging from $38.29 \pm 0.75 \mathrm{~kg}\left(\mathrm{~T}_{1}\right)$ to $39.55 \pm$ $0.62 \mathrm{~kg}\left(\mathrm{~T}_{3}\right)$ after 60 days of concentrate supplementation. For the does in Treatment 1, the body weights ranged from $34.59 \pm 0.75 \mathrm{~kg}$ (at the beginning) to $38.29 \pm 0.75 \mathrm{~kg}$ (after 60 days of supplementation) while for those in Treatment 2 it increased from $33.91 \pm$ 
Table-1. Cumulative live weight gain $(\mathrm{kg})$ of does during prepartum period.

\begin{tabular}{llll}
\hline Period & \multicolumn{3}{c}{ Treatments } \\
\cline { 2 - 4 } & $\mathbf{T}_{\mathbf{1}}$ & $\mathbf{T}_{2}$ & $\mathbf{T}_{3}$ \\
\hline $0-15$ & $0.45 \pm 0.21$ & $0.63 \pm 0.20$ & $0.70 \pm 0.28$ \\
$0-30$ & $1.14 \pm 0.21$ & $1.44 \pm 0.25$ & $1.60 \pm 0.28$ \\
$0-45$ & $2.19 \pm 0.21^{\mathrm{a}}$ & $2.88 \pm 0.23^{\mathrm{b}}$ & $3.20 \pm 0.35^{\mathrm{b}}$ \\
$0-60$ & $3.71 \pm 0.27^{\mathrm{a}}$ & $4.79 \pm 0.13^{\mathrm{b}}$ & $5.49 \pm 0.22^{\mathrm{c}}$ \\
\hline
\end{tabular}

Means bearing different superscripts in a row differ significantly $(P<0.05)$

Table-2. Cumulative live weight gain $(\mathrm{kg})$ of does during postpartum period.

\begin{tabular}{llll}
\hline Period & \multicolumn{3}{l}{ Treatments } \\
\cline { 2 - 4 } & $\mathbf{T}_{1}$ & $\mathbf{T}_{2}$ & $\mathbf{T}_{3}$ \\
\hline $0-15$ & $0.33 \pm 0.35$ & $0.26 \pm 0.39$ & $0.24 \pm 0.20$ \\
$0-30$ & $0.83 \pm 0.28$ & $0.67 \pm 0.47$ & $0.68 \pm 0.18$ \\
$0-45$ & $1.44 \pm 0.36$ & $1.10 \pm 0.45$ & $1.17 \pm 0.17$ \\
$0-60$ & $2.03 \pm 0.36$ & $1.43 \pm 0.46$ & $1.57 \pm 0.08$ \\
$0-75$ & $2.65 \pm 0.39$ & $1.85 \pm 0.52$ & $1.85 \pm 0.23$ \\
$0-90$ & $3.13 \pm 0.46^{a}$ & $2.19 \pm 0.48^{a b}$ & $2.10 \pm 0.19^{\mathrm{b}}$ \\
\hline
\end{tabular}

Means bearing different superscripts in a row differ significantly $(P<0.05)$

$0.70 \mathrm{~kg}$ to $38.71 \pm 0.64 \mathrm{~kg}$ while the corresponding figure for $\mathrm{T}_{3}$ ranged from $34.05 \pm 0.64$ to $39.55 \pm 0.62 \mathrm{~kg}$.

The does in treatment 2 and 3 showed higher body weights than those in treatment 1 in every 15 days interval till kidding although the difference was found to be statistically non-significant.

The cumulative live weight gains of does during prepartum period in different treatments are presented in Table-1. There is no statistically significant difference among the different treatments up to 30 days after concentrate supplementation. This might be due to less intake of concentrate during this period as the animals were not accustomed to concentrate feeding. The cumulative live weight gain of does was significantly higher in Treatment $3(3.20 \pm 0.35 \mathrm{~kg})$ during 0-45 days after supplementation than Treatment $1(2.19 \pm 0.21 \mathrm{~kg})$. The cumulative live weight gain during the period 0-60 days varied significantly among the different treatments with the lowest value in Treatment $1(3.71 \pm 0.27 \mathrm{~kg})$ to highest value in Treatment $3(5.49 \pm 0.22 \mathrm{~kg})$ although the initial body weights were same. The present findings indicate that the does in Treatment 1 were not able to meet their nutrient requirements exclusively from browsing and to meet the nutrient requirements for pregnancy; they might have mobilized their body reserve resulting in low body weights. The average daily gain of the does varied significantly among the different treatments during the prepartum period ranging from $61.78 \mathrm{~g}$ per day (Treatment 1 ) to $91.56 \mathrm{~g}$ per day (Treatment 3 ).

The higher body weight attained by the does in Treatment 2 and 3 might be attributed to the supplementation of balanced concentrates in these groups. The present finding is in agreement with the report of the earlier worker $[17,18]$ who reported a significant difference in the average body weight gain in different treatments due to supplementation of concentrate mixture during the last 2 months of gestation. In mid pregnancy the nutrient requirements of foetus are still low, but the placenta must grow during this period as the growth of placental tissue is restricted by low plane of nutrition as a result it will be unable to adequately nourish the foetus in final stage of pregnancy and consequently the birth weight will be compromised [4,5]. Rapid rate of foetal growth during the last 6-8 weeks of gestation imposes a metabolic challenge to the doe which is met by the mobilization of maternal body tissue [6]. This may result in weight loss of does if the dietary supply of nutrients is inadequate. Several authors have concluded that last month of gestation is the period of rapid foetal growth necessitating supplementation of pregnancy allowance to economize production and minimize reproduction loss in goats [15, 19]. But, earlier study [20] revealed that for economic animal production it may not be necessary to feed pregnant goats a high concentrate ration throughout the gestation period, but they should not be under fed between 61-120 days of pregnancy. The present finding is not in agreement with earlier study [21], who reported non-significant difference in the performance of adult and their off-springs among the pregnant does given no concentrate or different amount of concentrate before parturition.

The postpartum body weight of does at 15 days interval and cumulative live weight gain during postpartum period are presented in Figure 2 and Table 2 , respectively. The postpartum weight of does on the day of kidding ranged from $34.61 \mathrm{~kg}$ (Treatment 2) to $34.92 \mathrm{~kg}$ (Treatment 3). The loss of body weight in different treatments was respectively $3.44,4.10$ and $4.63 \mathrm{~kg}$ in Treatment 1, 2 and 3 from the prepartum body weight of the does after 60 days of concentrate supplementation. The current results are comply with the previous claims adapted by [4] who authenticated that supplementation increases the weight of foetus and more weight loss is obvious for the supplemental groups.

The cumulative body weight gain during 0-90 
days postpartum was significantly higher in Treatment 1 (non supplemented group) compared to Treatment 3 (300 g supplementation), but the difference between Treatment 1 and 2 was found to be non-significant. The cumulative live weight gain during 0-90 days postpartum period ranged from $2.10 \mathrm{~kg}$ (Treatment 3) to $3.13 \mathrm{~kg}$ (Treatment 1). The lower plane of nutrition of does in Treatment 1 in late gestation in comparison to Treatment 2 and 3 might have led to compensatory gain in former two treatment groups during lactation period. Similar types of reports have also been observed by earlier study [22,23]. But the present finding is not corroborated with the findings of $[8,19]$ who reported an increase bodyweight of doe at weaning because of the effect of supplementation.

The average daily gain of the does during the said period was $23.33 \mathrm{~g}$ per doe (Treatment 3 ), $24.30 \mathrm{~g}$ (Treatment 2) and $34.81 \mathrm{~g}$ (Treatment 1) per doe indicating a statistically significant difference among the treatments. The body weight gain of does during post partum period was significantly higher in Treatment 1 compared to Treatment 2 and 3 . The same type of observation is comply by $[22,23]$ because of compensatory growth in the supplemental groups in lactation period which is not so in the non supplemental group. While [19] found an opposite result of our present finding.

\section{Conclusion}

The present study to evaluate the growth performance of pregnant Ganjam goats by supplementation of concentrate mixture @ of 200 and $300 \mathrm{~g}$ in the prepartum period revealed that supplementation of concentrate between 160 to $225 \mathrm{~g}$ improved the periparturient body weight of pregnant Ganjam goats for optimum production under extensive system of management.

\section{Authors' contribution}

SS, LKB, DKK, KB and SK designed and conducted the experiment. SK, PB and JKP helped in analysis and drafting the manuscript. All authors read and approved the final manuscript.

\section{Acknow ledgments}

The authors are thankful to the Vice chancellor of Orissa University of Agriculture and Technology and Dean of College of Veterinary Science and Animal Husbandry, Bhubaneswar for providing necessary facilities in conducting the experiment.

\section{Competing interests}

Authors declare that they have no competing interest.

\section{References}

1. Asizua, D., Mpairwe, D., Kabi, F., Mutetikka, D., Kamatara, H., Hvelplund, T., Weisbjerg, M. R. and Madsen, J. (2010) AASAP and ESAP conference, Addis Ababa. <http://www.livepro-dc.life.ku.dk/IGMAFU-meat/ Publications/ /media/LiveProDC/docs/pdf/2010\% 205\% 20 Ar\%20Asizua $\% 20$ et $\% 20$ al $\% 202010 \% 20$ AASAP $\% 20$ and $\% 20$ ESAP $\% 20$ conference.ashx.> Retrived on 07-112012.

2. Kawas, J.R., Andrade-Montemayor, H. and Lu, C.D. (2010) Strategic nutrient supplementation of free-ranging goats. Small Rum. Res., 89: 234-243.

3. Mushi, D.E., Safari, J., Mtenga, L.A., Kifaro, G.C. and Eik, L.O. (2009) Effects of concentrate levels on fattening performance, carcass and meat quality attributes of Small East African $\times$ Norwegian crossbred goats fed low quality grass hay. Livestock Sc., 124: 148-155.

4. Acero-Camelo, A., Valencia, E., Rodríguez, A and Randel, P. F. (2008) Effects of flushing with two energy levels on goat reproductive performance. Livestock Research for Rural Development. (20) Article \#136. http://www.lrrd.org/lrrd20/ 9/acer20136.htm. Retrieved on 05-11-2012.

5. Rafiq, M., Khan, M.F. and Aujla, K.M. (2003) Economic benefits of lushing and supplemental feeding of salt-range ewes on pothwar ranges of Pakistan. Pakistan J. Biol. Sci., 6: 115.

6. Osuagwuh, A.I.A. and Aire, T.A. (1990) Intra uterine growth rates of the West Africa an dwarf goats and some fetal organs in relation to strategic feed supplementation during pregnancy.J. Vet. Med., 37: 198.

7. Hossain, M.E., Shajalal, M. Khan, M.J. and Hasanat, M.S. (2003) Effect of dietary energy supplementation of feed intake, growth and reproductive performance of goats under grazing condition. Pakistan J. Nutr., 2(3): 159.

8. Joshi, L., Thakur, Y. A. and Vader, M. L. (2004) Improving goat production in semiarid regions through better nutrition management. In: The contribution of small ruminants in alleviating poverty: communicating messages from research. Proceedings of the third DFID Livestock Production Programme link project (R7798) workshop for small ruminant keepers, Izaak Walton Inn, Embu, Kenya, 47 February, 2003 pp: 29-36.

9. Martin, G.B., Rodger, J. and Balache, D. (2005) Nutritional and environmental effect on reproduction in small ruminants. Repro. Fertility Dev., 16: 491.

10. Madibela, O. R. and Segwagwe, B. V. E. (2008) Nutritional effects of supplementary feeding on maternal blood metabolites, cortisol, thyroid hormones levels and on outcome of pregnancy of dry season kidding Tswana goats. Livestock. Res. Rural. Develop., 20 (4).

11. Patra, A.K., Sharma, K., Dutta, N. and Pattanaik, A.K. (2006) Effect replacement of dietary protein by a leaf meal mixture on nutrient utilization by goats in pre and late gestation. Small Rum. Res., 63: 66.

12. Totanji, A. L. and Lubbadeh, W. (2000) Effect of feeding different levels of energy and protein during the last two months of gestation on Shami goats performance in Jordan Valley. Dirasat. Agric. Sci., 27(2): 165-175.

13. Chaturvedi, O.H., Verma, D.L., Singh, N.P. and Man, J.S. (2008) Effect of concentrate supplementation on production performance of ewes grazing on community rangeland. Indian J. Anim. Sci., 78(10): 1162.

14. Dawson, E.R., Carson, A.F., Kilpatrick, D.J. and Laidlaw, A.S. (2005) Effect of herbage allowance and concentrate food level offered to ewes in late pregnancy on ewe and lamb performance. Brit. Soc. Anim. Sci., 81: 413.

15. Rastogi, A., Dutta, N. and Sharma, K. (2008) Effect of strategic feed supplementation during pregnancy on the performance of goats. Indian J. Anim. Sci., 78(1): 97.

16. Snedecor, G.W. and Cochran, W.G. (1994) Statistical methods. $8^{\text {th }}$ edition. Iowa State University Press, Ames, Iowa.

17. Chaturvedi, O. H., Mann, J. S. and Karim, S. A. (2010) Effect of concentrate supplementation to ewes grazing on community rangeland during late gestation and early lactation. Indian J.Small Rum., 16 (1): 97-100.

18. Ray, B. (2009) Effect of supplementation of concentrate on reproductive performance of grazing Ganjam goat in its native tract. M.V.Sc. Thesis, Dept. Animal Nutrition, C.V.Sc. 
\& A.H., Orissa University of Agriculture and Technology.

19. Bushara, I., Nikhaila, A.M.A and Mekki, D.M. (2010) Productive and reproductive traits of taggar goats as affected by type of ration under dry land farming System in western sudan. Eg. J. of Sheep \& Goat Sci., 5 (1): 209-220.

20. Osuagwuh, A.I.A. (1992) Effect of strategic feed supplementation during pregnancy on birth weight and perinatal survival of West African Dwarf kids. J. Agri. Sci., Cambridge, 119: 123.
21. Kayongo, S.B., Wanyoike, M. and Kayongo, M.H. (1984) Effect of pre and postpartum concentrate supplementation on productivity of Small East African goats grazed on range. Bull. Anim. Health Prod. Africa, 32(1): 31.

22. Ryan, W.J. (1990) Compensatory growth in cattle and sheep. Nutr.Abstr. Rev. (Series B), 60: 653.

23. Santra, A. and Pathak, N.N. (1999) Nutrient utilization and compensatory growth in crossbred (Bos indicus $\times$ Bos taurus) calves. Asian-Austr. J. Anim. Sci., 12: 1285.

$* * * * * * * *$ 